\title{
Plasma-desorption mass spectrometry as an express diagnostic test for bovine
} leukaemia

\author{
O. Bordunova*, L. Kovalenko, O. Chernenko, L. Bondarchuk, \\ I. Levchenko, N. Izmailova, T. Cherniavskaya and V. Chivanov
}

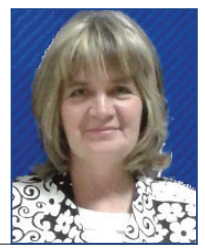

\begin{abstract}
Plasma-desorption mass spectrometry with ionization of ${ }^{252}$ Californium fission fragments $\left({ }^{252} \mathrm{Cf}-\mathrm{PD}\right.$ MS) was used to develop an express diagnostic test for bovine leukaemia. The test is based on the mass spectrometric parameters of artificial lipid membranes formed on the gold substrate from the lipid fraction of blood cells (mainly lymphocytes), by the self-assembly technique according to the biomimetic principle. Mass spectrometric analysis of artificial lipid membranes obtained from blood plasma of control and leukemic cattle gave a reliable diagnosis of leukaemia. The basis for the diagnosis were the ionization parameters of the fragmentation of lipid
\end{abstract}

molecules from normal and leukemic cell membranes. In leukemic cell membranes, separate dense areas (rafts) $200-300 \mathrm{~nm}$ in diameter, saturated with cholesterol and phospholipids, are formed. The number of rafts per unit of cell membrane of leukemic cells significantly exceeded the permitted parameters of normal cell membranes. The increased number of rafts in artificial membranes formed in the membranes of leukemic cells was reliably reflected in mass spectra, due to the $180-250 \%$ increase in intensity of peaks of cholesterol fragment ions in comparison to control cells.

Key words: bovine leukaemia; cholesterol; mass spectrometry; phosphocholine

\section{Introduction}

Leukaemia (lymphocytosis) of cattle is Enzootic bovine leucosis (EBL) caused by the bovine leucosis virus (BLV), and it remains a serious problem in industrial livestock production. Among

cattle diseases, leukaemia takes first places in the prevalence and number of fatal cases (Juliarena et al., 2017). Cattle of all age groups are susceptible to leukaemia. Clinically, the illness

Olga BORDUNOVA*, DVM, PhD, Full Professor, Sumy National Agrarian University, Faculty of Biology and Technology, Sumy, Ukraine (Corresponding author, e-mail: bordunova_olga@rambler.ru), Lidia KOVALENKO, DVM, PhD, Faculty of Veterinary Medicine, Sumy, Ukraine; Olexander CHERNENKO, DVM, PhD, Full Professor, Dnipro State Agrarian and Economic University, Dnipro, Ukraine; Larisa BONDARCHUK, PhD, Irina LEVCHENKO, PhD, Nataliy IZMAILOVA, PhD, Tatyana CHERNIAVSKAYA, PhD, Sumy National Agrarian University, Faculty of Biology and Technology, Ukraine; Vadym CHIVANOV, PhD, Institute of Applied Physics (IAP) NAS of Ukraine, Sumy, Ukraine 
manifests in animals over the age of 4 years. At first, the disease proceeds asymptomatically, then manifests as persistent lymphocytosis and/or the formation of tumour-like enlargements in the hematopoietic and other organs and tissues. Modern veterinary medicine offers methods for the clinical diagnosis of leukaemia. Diagnosis of cattle leukaemia should be based on the comprehensive application of traditional and modern instrumental research methods (Sami, 2018). For example, techniques of modern lipidomics make it possible to conduct a detailed study of the molecular structures of each specific subclass of lipid molecules (cholesterol and triglycerides) (Cvetkovic et al., 2009; Xiangdong et al., 2018). The main objective of this study was to diagnose cattle leukaemia based on the study of the spatial arrangement of lipids of different classes in an artificial layered molecular structure using plasma-desorption mass spectrometry with ionization of ${ }^{252}$ Californium fission fragments $\left({ }^{252} \mathrm{Cf}-\right.$ PD MS; PDMS) (MacFarlane, 2017). The theoretical basis for the study was that the study of lipid exchange in leukemic cattle using the latest mass-spectrometric methods, in contrast to humane medicine, is extremely inadequate (Cvetkovic et al., 2009; Bandu et al., 2018; Xiangdong et al., 2018).

\section{Materials and Methods}

The study was carried out during 2006 - 2018 in the Clinical-diagnostic Centre of the Faculty of Veterinary medicine and the Department of Biochemistry and Biotechnology, Sumy NAU, and Department №20 of the Institute of Applied Physics of NAS of Ukraine, Sumy, Ukraine.

Sampling. Blood samples from healthy animals (norm; Norma) and animals with leukaemia (Bovine leukaemia; Leu) were kindly provided by the staff of the Sumy Regional Veterinary Laboratory (preliminary diagnosis was performed by immunodiffusion in agar gel (RID). In total, serum and plasma samples from 512 cattle were used in the screening experiment (BLV antibodies) by RID, and the results gave 102 negative samples and 410 positive samples. All positive samples were then analysed by mass spectrometry.

Biochemical analysis. To diagnose cattle leukaemia in the Ukrainian Red dairy breed, Holstein breed and Simmental breed (animals aged 4-5 years), chloroform extracts from blood samples obtained by J. Folch's standard method with modifications were examined (Semionov et al., 2007). Blood was drawn from animals 3-4 hours after the last feeding, provided that the diet was standard. Extraction of the lipid fraction was carried out using a mixture of chloroform-methanol (volume ratio 9:1; $\mathrm{pH}$ $3.5\left(\mathrm{CH}_{3} \mathrm{COOH}\right)$, which was added to 40 $\mu \mathrm{L}$ homogenized blood and maintained at $+37^{\circ} \mathrm{C}$ for 2 hours. Samples of the lipid fraction of animal blood were prepared by applying $10 \mu \mathrm{L}$ chloroform-methanol extracts of blood to the surface of a goldplated sample carrier mass spectrometer, followed by drying at $+20^{\circ} \mathrm{C}$ in a nitrogen atmosphere. The stain diameter of the specimens was $4.5-5.0 \mathrm{~mm}$. To study changes in the level of protein adsorption on lipid molecules in the blood samples of healthy and leukemic cattle, $30 \mu \mathrm{L} \mathrm{10 \%}$ aqueous solution bovine immunoglobulin G (Sigma-Aldrich) $(\mathrm{pH}=6.0-6.5 ; 3-4)$ and/or human serum albumin (SigmaAldrich) $(\mathrm{pH}=6.0-6.5 ; 3-4)$ were applied to a thin layer of lipid extract previously dried on a gold-plated sample carrier disc. Adsorption was carried out at $37^{\circ} \mathrm{C}$ for $5 \mathrm{~min}$. and dried. For analysis of samples of lipid blood extracts, a time-offlight plasma-desorption mass spectrometer with ionization of the ${ }^{252} \mathrm{Cf}$ fission fragments was used (instrument MSBH, JSC SELMI, Sumy, Ukraine). The peaks of 
quasimolecular ions (QMI) of lipids in the mass spectra were considered suitable for possible identification, provided that the signal:noise ratio was greater than or equal to 3:1 (DeHoffman and Stroobant, 2007). The figures show typical mass spectra. The $y$-axis shows the intensities of the peaks of ions and their fragments in arbitrary units (a.u.) or the number of ions (counts) obtained using photoelectronic multipliers. Both are relative units, which allow the use of time-of-flight mass spectrometer for semi-quantitative measurements in the presence of appropriate control samples (in our case, samples of lipid blood extracts from healthy animals) (MacFarlane, 2017). The studies were performed using a general scheme of mass spectrometric lipidomics (Xiangdong et al., 2018).

Statistical analysis. Statistical evaluation of the results was conducted using the arithmetic mean \pm standard deviation $(x \pm S D)$. The results on the figures are expressed as $\mathrm{x} \pm \mathrm{SD}$. The data were processed statistically using the software packages Statistica 99Ed., StatSoft Inc

\section{Results}

The development of an instrumental approach for the diagnosis of cattle leukaemia based on qualitative and quantitative indicators of the total lipid fraction of venous blood, taking into account changes of the adsorption affinity of blood phospholipids and serum proteins, was previously described by Raguz et al. (2011). It is known that tumour development in animals is characterized by significant disorders of lipid metabolism in tissues and organs, which is reflected in the change in the blood lipid spectrum (Musolino et al., 2002; Yavasoglu, 2017; Zalba and Ten Hagen, 2017; Furong et al., 2018). It should also be considered that malignancies significantly alter the physicochemical properties of membrane structures, including phospholipids (Einollahi et al., 2013). The solution to this problem was carried out, taking into account the analytical capabilities of the highly sensitive mass spectrometric method soft ionization a time-of-flight plasma desorption mass spectrometry $\left({ }^{252} \mathrm{Cf}-\mathrm{PD}\right.$ MS) (MacFarlane, 2017). Bordunova et al. (2005) previously showed that sensitivity of the MSBH device is $10 \mathrm{nmoL}$ mellitin (Sigma-Aldrich) $/ 5 \mu \mathrm{L} \quad 1 \% \mathrm{CH}_{3} \mathrm{COOH}$. It has previously been shown that ${ }^{252} \mathrm{Cf}$ PD MS is highly effective for the analysis of multicomponent samples containing thermolabile non-volatile substances, including lipids of animal and plant origin, proteins, nucleic acid components, vitamins, pharmacological substances, etc. (MacFarlane, 2017). The obtained mass spectra identified quasi-molecular ions (QMI) that correspond to the structural component of phospholipids and sphingolipids - phosphocholine (PC) $[\mathrm{M}]+$ and cholesterol (Ch) fragment; [M18] + with molecular weights of 182.3 $(184.0 \pm 2.0)$ a.m.u. (atomic mass unit; $\mathrm{m} / \mathrm{z}$ ) and $366.9(367 \pm 2.0)$ a.m.u. accordingly (Fig. 1). The peak intensity of these ions (J) was determined in relative units on the y-axis (signal intensity; counts) (Fig. 1). The first part of the experiment was to compare the mass spectra obtained from samples of chloroform extracts of the serum of healthy and leukemic cattle. As seen in Fig. 2, intense phosphocholine $\mathrm{Ph}$ ions and cholesterol $\mathrm{Ch}$ ions can be reliably identified in all mass spectra of the extracts, though no significant difference was found between healthy and diseased animals. According to the MacFarlane (2017), this may be due to the heterogeneity of the lipid layer on gold, which in turn has a critical effect on ionization in the ${ }^{252} \mathrm{Cf}$ -PD MS method by MacFarlane (2017). On the contrary, the study of model membranes of the "lipid-protein" type showed a significant difference between the mass spectra obtained for leukaemia 


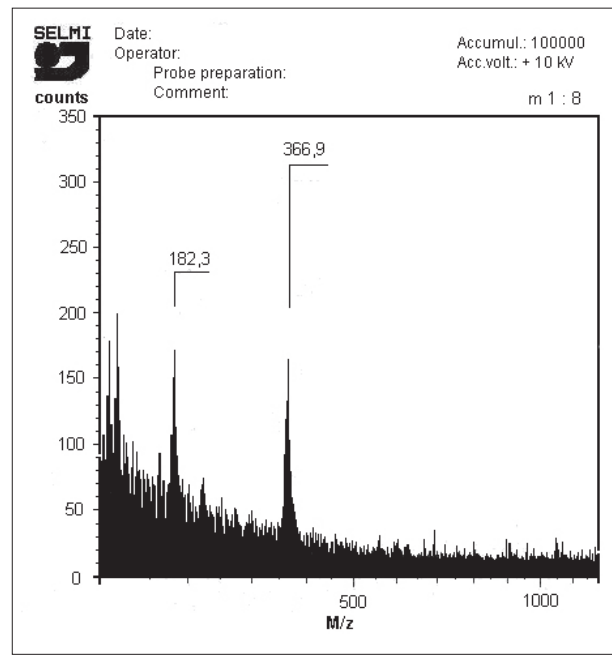

Figure 1. Mass spectrum of ${ }^{252} \mathrm{Cf}$ PD MS lipid extract from cattle serum lion peak with a mass of 182.3 a.m.u $(\mathrm{m} / \mathrm{z})$ corresponds to phosphocholine $(\mathrm{Ph})$, ion with mass of 366.9 a.m.u $(\mathrm{m} / \mathrm{z})$ corresponds to the cholesterol fragment Ch [cholesterol - 18] +

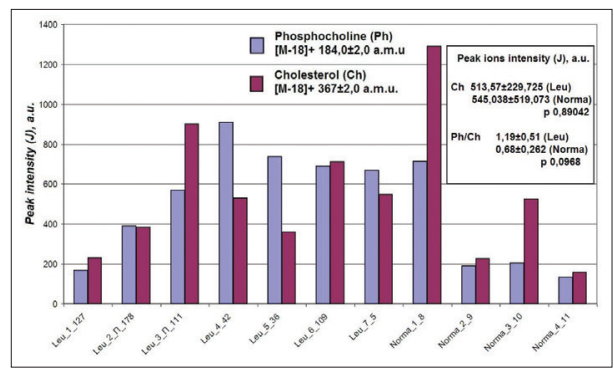

Figure 2. Intensity of two characteristic Ph and Ch ions in the mass spectra of chloroform serum lipid extract in control (Norma) and leukemic (Leu) cattle blood samples (sample preparation method - drying by air jet $10 \mu \mathrm{L}$ of the extract on a gold substrate

and healthy animals (Fig. 3, 4). In the case of leukaemia, the intensity of the specific cholesterol peak (Ch; 367.0 a.m.u.; $\mathrm{m} / \mathrm{z}$ ) exceeded the corresponding phosphocholine peak ( $\mathrm{pH} ; 184.0$ a.m.u.; $\mathrm{m} / \mathrm{z}$ ) by $150-170 \%$. In the case of norms, such a dependence is absent (Fig. 3). This series of experiments used an IgG solution with a neutral value of acidity

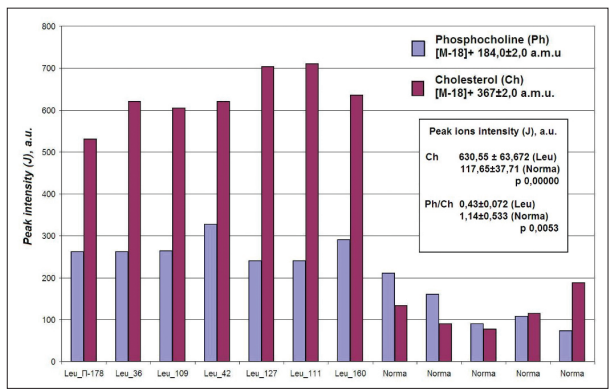

Figure 3. The intensity of the two characteristic $\mathrm{Ph}$ and $\mathrm{Ch}$ ions in the mass spectra of serum lipid extracts of control (Norma) and leukemic (Leu) cattle blood samples (sample preparation method - $10 \mu \mathrm{L}$ of serum chloroform extract was applied to the surface of the gold substrate, $30 \mu \mathrm{L}$ $10 \%$ aqueous solution bovine immunoglobulin $G$ (Sigma, USA) ( $\mathrm{pH}=6.0-6.5 ; 3-4)$. Adsorption was carried out at $20^{\circ} \mathrm{C}$ for 5 minutes, then dried with a jet of air without rinsing

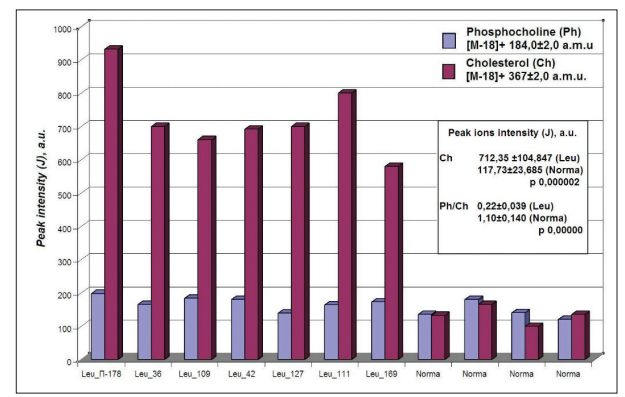

Figure 4. The intensity of two typical $\mathrm{Ph}$ and $\mathrm{Ch}$ ions in the mass spectra of of serum chloroform extract of serum blood lipids in control (Norma) and leukemic (Leu) cattle blood samples lof sample preparation method - $10 \mu \mathrm{L}$ of serum chloroform extract was applied to the surface of the gold substrate, then $30 \mu \mathrm{L} 10 \%$ aqueous solution bovine immunoglobulin $\mathrm{G}$ (Sigma, USA) ( $\mathrm{pH}=3-4$ ). Adsorption was carried out at $20^{\circ} \mathrm{C}$ for 5 minutes, then dried with a jet of air without flushing

$(\mathrm{pH}=6.0-6.5)$. Increasing the acidity of the IgG solution $(\mathrm{pH}=3.0-4.0)$ led to more contrasting results. Both the total intensity of the Ch peak obtained in the analysis of serum samples of leukemic animals, and the ratio of the intensities of the peaks of $\mathrm{Ch}$ and $\mathrm{Ph}$ ions increased. The cholesterol fragment ions (Ch) exceeded phosphocholine ions (Ph) by $250-380 \%$ 
(Fig. 4). Under the conditions of structure formation of artificial membranes on the gold substrate in an acidic medium, as in the previous case, the control samples also showed no significant differences.

\section{Discussion and conclusions}

In our earlier research on the mass spectrometric study of lipids of biological samples, it was determined that cholesterol $(\mathrm{Ch})$, its fragments, phospholipids, sphingolipids and their structural components (PC) are good objects for mass spectrometric identification in multicomponent sums mass numbers (a.m.u; $\mathrm{m} / \mathrm{z}$ ) of their quazimolecular ions (QMI) (Semionov et al., 2007). Accordingly, from the standpoint of the mass spectrometric ${ }^{252} \mathrm{Cf}-\mathrm{PD} \mathrm{MS}$ analysis of total undivided blood lipid samples, molecules such as $\mathrm{PC}$ and $\mathrm{Ch}$ are good diagnostic markers. This feature of the ${ }^{252} \mathrm{Cf}-\mathrm{PD} \mathrm{MS}$ is the simultaneous identification of QMI of an organic substance $\mathrm{M}^{+(-)}$and the scheme acquisition of a road fragmentation of the same ion with high excitation in one dimension, which is unique among mass spectrometric methods using desorption/ ionization processes (Kinoshita et al., 2018). Another important feature of the ${ }^{252} \mathrm{Cf}-\mathrm{PD} \mathrm{MS}$ is the ability to provide local analysis of an organic sample at the nanoscale level, given its ability to examine the microscopic heterogeneity of multicomponent organic substances samples at the nanometre level. If a sample consists of two chemically homogeneous components that are also capable of forming on the surface of a solid substrate similar to organic crystals, quasi-ordered nanoscale structures that separate components are in close proximity (up to $10 \mathrm{~nm}$ ). The mass spectrum simultaneously records intense ion peaks inherent to both components ejected during one ${ }^{252} \mathrm{Cf}$ fission from one "ultra and infratrack". The size of the track is up to $20 \mathrm{~nm}$ in diameter and 10 $\mathrm{nm}$ depth of the sample. However, if these components are localized within the matrix at distances exceeding $10 \mathrm{~nm}$, then they can be accurately determined by the characteristics of the corresponding ions (intensity, charge value, etc.). This feature of the ${ }^{252} \mathrm{Cf}-\mathrm{PD}$ MS provides the method with a unique opportunity to approximately identify the intermolecular distances of organic target substances in the matrix (MacFarlane, 2017). It is this ability of the ${ }^{252} \mathrm{Cf}-\mathrm{PD}$ MS method to work as a "spatial nanotester" that formed the basis of an experiment to study the adsorption of proteins on the surface of dried lipid extract of blood from healthy and sick cattle with leukaemia, with the possibility of further applications of these results in the diagnosis of the disease. The basic principle of the study was that the biomimetic model is an artificial membrane consisting of a mixture of total lipids and proteins (as typical obligate components of blood albumin and immunoglobulin $\mathrm{G}$, which are inhomogeneous in quantitative and qualitative aspects) obtained from extracts of blood samples of control and leukemic cattle (Mason et al., 2003; Raguz et al., 2011). In particular, it was shown that under conditions of diseases of different origin and in particular cell malignancy, lipid rafts are special sections (microdomains) of the plasma membrane (enriched on glycosphingolipids and cholesterol) that are observed in the bilayer cell membranes (Musolino et al., 2002). These sites coordinate cellular processes, affect membrane fluidity, serve as centres of organization for the formation of signalling molecules, regulate the movement of membrane proteins and receptors, and regulate the processes of neurotransmission. Lipid rafts are more structured and arranged more densely than the double layer of lipids surrounding them; they are surrounded by protein molecules all 
around the perimeter that are able to move freely within that perimeter (Mason et al., 2003; Kinoshita et al., 2018).

In tumour cells, the affinity of proteins to lipids is significantly reduced, due to changes in the composition of membrane lipids and the physicochemical properties of interacting molecules. Thus, the ${ }^{252} \mathrm{Cf}$ PD MS method allows for identification and evaluation of the degree of heterogeneity of artificial membranes formed on the biomimetic principle on the gold substrate. Based on this data, it is possible to establish a correlation between this heterogeneity and the presence of leukaemia (Mason et al., 2003).

In some cancers, tumour cell membranes and normal tissues surrounding the tumour have an increased lipid content. These changes are associated with a number of mechanisms, such as an increase in circulating Ch absorption, stimulation of endogenous synthesis, and the blocking of excess cholesterol from cells during the process of malignant transformation. Lipid metabolism in tumours is accelerated, due to the high intensity of cell division, as a necessary condition for the synthesis of lipid components of the cytoplasmic membrane (Zalba and Ten Hagen, 2017; Laxman et al., 2019). The increase in the production of these substances, including $\mathrm{Ch}$, has been observed for leucocytosis, as shown for Marek's disease (Semionov et. al., 2007). This in turn causes an increase in the synthesis of ceramides and, accordingly, phosphocholine, as a signalling molecule of apoptosis. Thus, changes in the amount of PC and $\mathrm{Ch}$ in the blood of cattle with leukaemia are expected. A particular theme is the peculiarity of the process of blood protein adsorption to lipids (Huang and Kennel, 1979; Mason et al., 2003; Zalba and Ten Hagen, 2017). In view of this, the experimentally proven effect of a multiple increase in the intensity of peaks of the quasimolecular cholesterol ion (Ch) in studying artificial membranes formed on a gold substrate by the biomimetic principle of immunoglobulin molecules (IgG) and the serum lipid fraction of leukemic cattle can be explained as: a) a ${ }^{252} \mathrm{Cf}$ fission fragment allows for the identification of defects in the "raft" membrane that are not in control, and/or, b) a layer of immunoglobulin $G(\operatorname{Ig} G)$ selectively adsorbs cholesterol (Ch) molecules with the formation of surface structure at the nanoscale, which ionizes more efficiently in comparison to the more disordered structures. Figure 5 shows the ionization processes of the sample molecules under the influence of ${ }^{252} \mathrm{Cf}$ fission fragments in the mass spectrometric analysis after adsorption of immunoglobulin $\mathrm{G}$ molecules on the surface of the artificial membrane with the formed "rafts" (Dietrich et al., 2001; Bieberich, 2018).

With the use of plasma desorption mass spectrometry with ionization of the ${ }^{252} \mathrm{Cf}$ fission fragments $\left({ }^{252} \mathrm{Cf}-\mathrm{PD} \mathrm{MS}\right.$ mass spectrometry), a test for rapid diagnosis of cattle leukaemia was developed. The test is based on the study of quantitative and qualitative parameters of artificial lipid-protein membranes formed on a gold surface from membranes of cells by self-structuring of the liquid phase by the biomimetic principle. ${ }^{252} \mathrm{Cf}-\mathrm{PD} \mathrm{MS}$ analysis of serum lipid of control and leukemic cattle can reliably diagnose leukaemia based on the analysis of ionization and fragmentation of phospholipid (PC) and cholesterol (Ch) molecules forming in natural and artificial membranes lipid rafts $200-300$ $\mathrm{nm}$ in size, saturated with cholesterol and phospholipids molecules. It was shown here that the increased amount of lipid rafts in the model membranes from the lipid fraction of the plasma of leukemic cattle is significantly reflected in the 180 - $250 \%$ increase in the intensity of peaks of the cholesterol fragment (Ch-18) with a molecular mass values from 366 to 370 a.m.u. $(\mathrm{m} / \mathrm{z})$ in the control. 


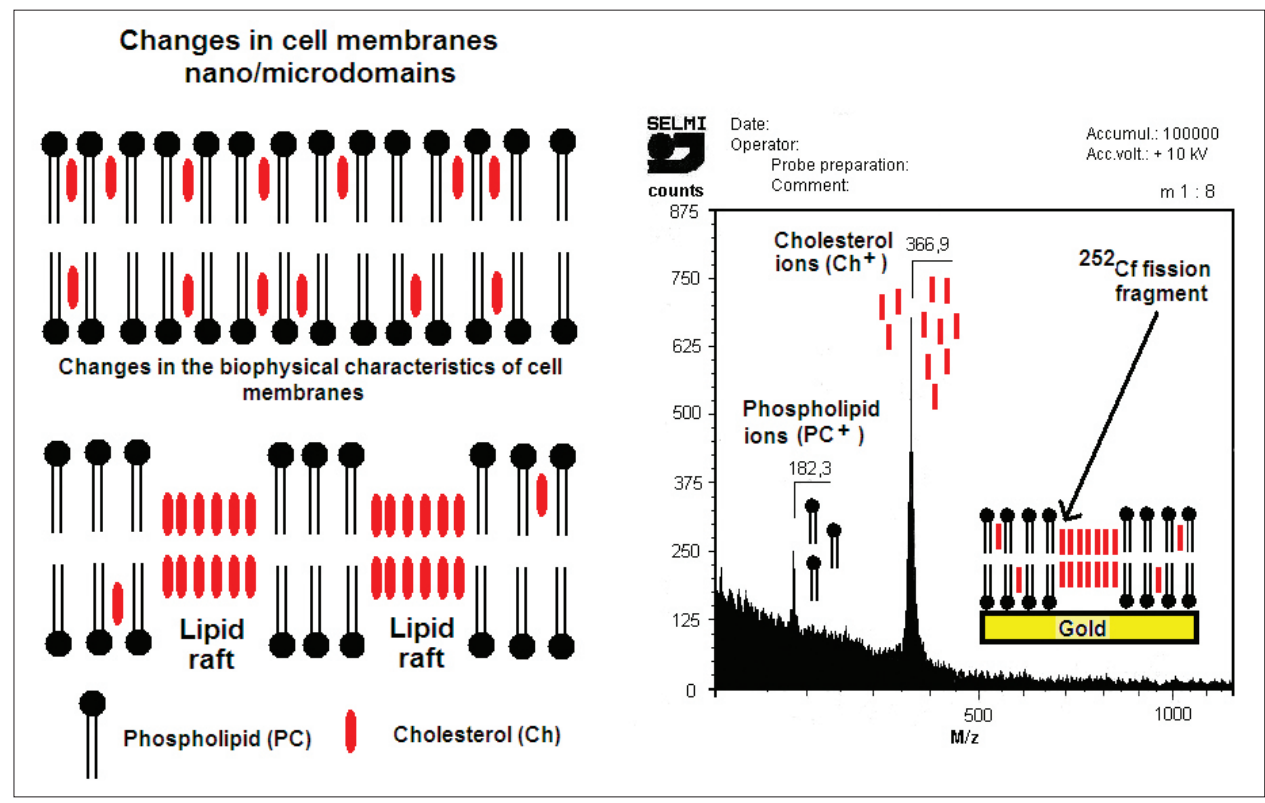

Figure 5. Scheme of membrane formation at the level of micro- and nanodomains of supramolecular complexes of lipids and proteins under conditions of malignancy processes (left) and formation of ions, which are responsible for cholesterol and phosphocholine ions in the ${ }^{252} \mathrm{Cf}-\mathrm{PD}$ MS method (right)

\section{Financial Support}

This work was supported by the NDD KR Ukraine (state registration number 0118U006179).

\section{References}

1. BANDU, R., J. M. HYUCK and K. P. KWANG (2018): Phospholipids as a Cancer Biomarkers: Mass Spectrometry-Based Analysis. Mass Spec Rev. 37, 107-138.

2. BIEBERICH, E. (2018): Sphingolipids and lipid rafts: Novel concepts and methods of analysis. Chem. Phys. Lipids 216, 114-116.

3. BORDUNOVA, O. et al. (2005): Protein-peptide components of shell bioceramic matrix of hen incubatory eggs under the influence of different factors of environment. Agricult. Biol. 40, 51-56.

4. CVETKOVIC, Z., B. CVETKOVIC, M. PETROVIC, M. RANIC, J. DEBELJAKMARTARCIC, V. VUCIC and M. GLIBETIC (2009): Lipid profile as a prognostic factor in cancer patients. J. Buon. 14, 501-506.

5. DE HOFFMAN, E. and V. STROOBANT (2007): Mass spectrometry. Principles and Applications, Wiley.

6. DIETRICH, C., L. A. BAGATOLLI, Z N VOLOVYK, N. L. THOMPSON, M. LEVI, K. JACOBSON and
E. GRATTON (2001): Lipid Rafts Reconstituted in Model Membranes. Biophys. J. 80, 1417-1428.

7. EINOLLAHI, N., Sh. ALIZADEH, N. NABATCHIAN, M. ZARE BOVANI, S. ABBASI, M. MOHAMADIAN and Z. KASHANI KHATIB (2013): Serum Lipid Profile Alterations in Acute Leukemia Before and After Chemotherapy. Iran J. Blood Cancer 6: 3-9, url: http://ijbc.ir/article-1-430-en.html.

8. FURONG, Y., Z. HONG and Z. YIMING (2018): Lipidomics: a promising cancer biomarker. Clin. Transl. Med. 7, 21. https://dx.doi.org/10.1186/ s40169-018-0199-0

9. HUANG, L. and S. J. KENNEL (1979): Binding of immunoglobulin $G$ to phospholipid vesicles by sonication. Biochemistry 18, 1702-1707.

10. JUliARENA, M., C. N. BARRIOS, C. M. LÜTZELSCHWAB, E. N. ESTEBAN and S. E. GUTIÉRREZ (2017): Bovine leukemia virus: current perspectives. Virus Adaptation and Treatment 9, 13-26.

11. KINOSHITA, M., G. N. KENICHI, M. M. SUZUKI and M. NOBUAKIO (2018): Evidence of lipid rafts based on the partition and dynamic behaviour of sphingomyelins. Chem. Phys. Lipids 215, 84-95.

12. LAXMAN, M., W. J. O'BRIEN and W. K. SUBCZYNSKI (2019): Detection of cholesterol bilayer domains in intact biological membranes: Methodology development and its application to studies of eye lens fiber cell plasma membranes. Exp. Eye Res. 178, 72-81. 
13. MACFARLANE, R. D. (2017): Plasma Desorption Ionization Using ${ }^{252} \mathrm{Cf}$ in Mass Spectrometry. Encyclopedia of Spectroscopy and Spectrometry, (Third Ed.), pp. 667-675.

14. MASON, R., T. N. TULENKO and R. F. JACOB (2003): Direct evidence for cholesterol crystalline domains in biological membranes: role in human pathobiology. Biochim. Biophys. Acta 1610, 198-207.

15. MUSOLINO, C., L. CALABRO and G. BELLOMO (2002): Lipid profile in hematologic neoplasms. Recenti. Prog. Med. 93, 298-301.

16. RAGUZ, M., L. MAINALI, J. WIDOMSKA and W. K. SUBCZYNSKI (2011): The immiscible cholesterol bilayer domain exists as an integral part of phospholipid bilayer membranes. Biochim. Biophys. Acta 1808, 1072-1080.

17. SAMI, M. (2018): Chronic Lymphocytic Leukemia: Methods and Protocols. In: N. J. Clifton (Ed.)
Methods in molecular biology, Humana Press, Springer.

18. SEMIONOV, D. et al. (2007): Mass spectrometric method for diagnosing Marek's disease in chickens. Patent number: 80939 Published: 26.11.2007 (19) UA (11) 80939 (13) C2 (51) МПК (2006) A61B 5/00 G01N 33/49 [in Ukrainian].

19. XIANGDONG, W., W. DUOJIAO and S. HUALI (2018): Lipidomics in Health \& Disease: Methods \& Application. 204. In: Translational Bioinformatics 14. Springer, Singapore VI.

20. YAVASOGLU, I., G. SARGIN, F. YILMAZ et al. (2017): Cholesterol Levels in Patients with Chronic Lymphocytic Leukemia. J. Natl. Med. Assoc. 109, 23-27.

21. ZALBA, S. and T. L. M. TEN HAGEN (2017): Cell membrane modulation as adjuvant in cancer therapy. Cancer Treat. Rev. 52, 48-57.

\section{Desorpcija plazme pomoću masene spektrometrije kao brzi test za dijagnostiku leukemije goveda}

Dr. sc. Olga BORDUNOVA, dr. med. vet., redovita profesorica, Nacionalno Agrarno Sveučilište Sumy, Biološki i tehnološki fakultet, Sumy, Ukrajina; dr. sc. Lidia KOVALENKO, dr. med. vet., Veterinarski fakultet, Sumy, Ukrajina; dr. sc. Oleksandr ČERNENKO, dr. med. vet., redoviti profesor, Državno Agrarno-Ekonomsko Sveučilište u Dnjepru, Dnjepar, Ukrajina; dr. sc. Larisa BONDARCHUK, dr. sc. Irina LEVCHENKO, dr. sc. Nataliy IZMAILOVA, dr. sc. Tatjana CHERNIAVSKAYA, Nacionalno Agrarno Sveučilište Sumy, Biološki i tehnološki fakultet, Sumy, Ukrajina; dr. sc. Vadym CHIVANOV, Institut za primijenjenu fiziku (IAP) NAS u Ukrajini, Sumy, Ukrajina

Korištenjem desorpcije plazme pomoću masene spektrometrije s ionizacijom fragmenata fizije ${ }^{252}$ kalifornijskih fragmenata fizije ( ${ }^{252} \mathrm{Cf}-\mathrm{PD} \mathrm{MS}$ ) razvijen je brzi test za dijagnostiku leukemije goveda. Istraživanje se temelji na masenim spektrometrijskim pokazateljima umjetnih lipidnih membrana formiranih na zlatnom supstratu iz lipidne frakcije krvnih stanica (uglavnom limfocita) samo-sastavnom tehnikom prema biomimetičkom principu. Masena spektrometrijska analiza lipidnih umjetnih membrana dobivenih iz krvne plazme kontrolne skupine i skupine goveda oboljelih od leukemije omogućava pouzdanu dijagnozu leukemije. Osnova za dijagnozu bili su pokazatelji ionizacije i fragmentacije lipidnih molekula iz normalnih staničnih membrana i leukemijskih stanica. U membranama leukemijskih stanica formiraju se zasebna gusta područja (tzv. splavi) promjera 200 - $300 \mathrm{~nm}$, zasićena kolesterolom i fosfolipidima. Broj splavi po jedinici stanične membrane leukemijskih stanica znatno je veći od odgovarajućih pokazatelja membrane normalnih stanica. Povećani broj splavi u umjetnim membranama formiranim iz membrana stanica goveda oboljelih s leukemijom pouzdano se odražava u masenim spektrima u povećanju intenziteta vrhunaca iona fragmenata kolesterola za $180-250 \%$ u usporedbi sa skupinom kontrolnih goveda.

Ključne riječi: leukemija goveda, kolesterol, masena spektormetrija, fosfokolin 